\section{Ornamental Cabbage Quality Improved by Continual Fertilization through Center-head Coloration}

\author{
James L. Gibson ${ }^{1}$ and Brian E. Whipker ${ }^{2}$ \\ Department of Horticultural Science, Box 7609, North Carolina State University, \\ Raleigh, NC 27695-7609
}

Additional index words. Brassica oleracea var. acephala, nitrogen, potassium, tissue analysis.

\begin{abstract}
Current fertilizer recommendations for ornamental cabbage (Brassica oleracea var. acephala DC.) suggest applying 150 to $300 \mathrm{mg} \cdot \mathrm{L}^{-1} \mathrm{~N}$ until the initiation of color development, after which fertilization should be reduced or discontinued. Because these plants are actively growing during cool weather when coloration is initiated, nutrient deficiencies may reduce overall plant quality. The objectives of this study were to investigate $N$ to $K$ ratios for plant growth of ornamental cabbage and the effects of continual and discontinued fertilization during the period of coloration. Fertilizing with 150 to $200 \mathrm{mg} \cdot \mathrm{L}^{-1} \mathrm{~N}$ and 150 to $200 \mathrm{mg} \cdot \mathrm{L}^{-1} \mathrm{~K}$ produced high-quality plants and provided sufficient tissue concentrations of $\mathbf{N}$ and $\mathrm{K}$. Center-head coloration was not inhibited by $\mathbf{N}$ concentrations as high as $250 \mathrm{mg} \cdot \mathrm{L}^{-1}$. Ceasing fertilization prior to center-head coloration resulted in the rapid depletion of $\mathrm{N}$, $\mathrm{P}$, and $\mathrm{K}$ concentrations in the lower foliage, leading to the appearance of deficiency symptoms and lower leaf loss. Plants were still actively growing as measured by increased shoot mass during the early stages of coloration; therefore, growers should continue to provide a complete analysis fertilizer at $N$ concentrations $\geq 150 \mathrm{mg} \cdot \mathrm{L}^{-1}$ until market date.
\end{abstract}

Ornamental cabbage is an important fall crop for greenhouse growers in the southeastern United States. During the establishment and growing phase of the crop, growers traditionally use a continual liquid fertilization program similar to that used for garden chrysanthemums (Whipker et al., 1998), but fertilizer recommendations vary by source. Marquardt and Schlemmer (1996) suggest fertilizing with $150 \mathrm{mg} \cdot \mathrm{L}^{-1} \mathrm{~N}$, while McAvoy (1994) and Luczai (1992) recommend $\mathrm{N}$ at 50 to $100 \mathrm{mg} \cdot \mathrm{L}^{-1}$ during the seedling stage, followed by 200 to $300 \mathrm{mg} \cdot \mathrm{L}^{-1}$ after transplanting. All of the above references suggest a reduction or complete cessation of fertilization during color development in the upper-central foliage, which occurs when temperatures drop to 12.7 to 15.5 ${ }^{\circ} \mathrm{C}$ (Galinat, 1995). Excessive fertilization is thought to inhibit coloration (Luczai, 1992).

Received for publication 15 July 2002. Accepted for publication 31 Dec. 2002. This research was supported by the Florida Agricultural Experiment Station (FAES) and approved for publication as Journa Series No. R-09884. This research was funded in part by the North Carolina Agricultural Research Service (NCARS), Raleigh, NC 27695-7643. Use of trade names in this publication does not imply endorsement by the FAES or NCARS of products named nor criticism of similar ones not mentioned. Appreciation is given to Fred C. Gloeckner for supplying the seeds Ingram McCall for her technical support; Wagner Greenhouses, Minneapolis, Minn., for the seedling plugs; Fafard, Inc. for the root substrate; The Scotts Co. for the fertilizer; and for grant support, the Fred C. Gloeckner Foundation, the Uniroyal Chemical Co., and the North Carolina Commercial Flower Growers' Assn.

${ }^{1}$ Former Graduate Research Assistant. Current address: Univ. of Florida, IFAS-Milton Campus, 5988 Highway 90, Building 4900, Milton, FL 32583. ${ }^{2}$ Associate Professor.

HortScience, Vol. 38(7), DeCEMber 2003
4 sphagnum peat : 2 pinebark : 2 vermiculite : 1 perlite (by volume). A continual liquid fertilization program was initiated on $19 \mathrm{Feb}$. with a $4 \times 4 \mathrm{~N}-\mathrm{K}$ factorial with $\mathrm{N}$ and $\mathrm{K}$ levels varying from $100,150,200$, to $250 \mathrm{mg} \cdot \mathrm{L}^{-1}$ in a completely randomized design with five singleplant replications. Ammoniacal-nitrogen was $32 \%$ to $39 \%$ of the total nitrogen in all treatments with all other nutrients constant among treatments (Gibson, 2000). Macronutrients and micronutrients were from reagent grade salts. Foliar sprays of daminozide (2,2-dimethylhydrazide) (B-Nine, Uniroyal Chemical, Middlebury, Conn.) at $2500 \mathrm{mg} \cdot \mathrm{L}^{-1}$ (using a volume of $204 \mathrm{~mL} \cdot \mathrm{m}^{-2}$ ) were applied on $23 \mathrm{Feb}$. and 5 Mar. Plants were grown under natural daylength with greenhouse setpoint temperatures of $18.3^{\circ} \mathrm{C}$ day $/ 15.5^{\circ} \mathrm{C}$ night until $6 \mathrm{Apr}$. From 6 until $22 \mathrm{Apr}$., the plants were placed in a dark cooler at $7.2{ }^{\circ} \mathrm{C}$ for $12 \mathrm{~h}(19: 00-07: 00 \mathrm{HR})$ to induce color development and returned to the greenhouse during the day.

On 12 Mar. and 6 Apr., plant height (measured from the pot rim to the top of the plant) and plant diameter (measured at the widest dimension and then turned $90^{\circ}$ ) were recorded. On 22 Apr., plant height, plant diameter, and diameter of the white portion of the rosette were recorded.

Plant tissue (first mature leaves from the apex of the plant) was harvested on $22 \mathrm{Apr}$. Tissue was washed in $0.5 \mathrm{~N} \mathrm{HCl}$ for $1 \mathrm{~min}$ and rinsed with deionized water before drying at 70 ${ }^{\circ} \mathrm{C}$ for tissue analysis. Dried tissue was ground in a stainless steel Wiley mill to pass through a 1-mm (20-mesh) screen. Nitrogen concentration was analyzed using a Perkin-Elmer PE $2400 \mathrm{CHN}$ elemental analyzer (Perkin-Elmer, Norwalk, Conn.). Tissue for $\mathrm{P}, \mathrm{K}, \mathrm{Ca}$, and $\mathrm{Mg}$ analyses was dry-ashed at $500{ }^{\circ} \mathrm{C}$, dehydrated in $3 \mathrm{~N} \mathrm{HCl}$, and dissolved in $0.5 \mathrm{~N} \mathrm{HCl}$. All the elements were measured using an inductively coupled plasma emission spectrometer (PerkinElmer Plasma 2000 system, Perkin-Elmer).

Nitrogen fertilization concentration (Expt. 2). Plugs $(2.1 \times 2.1 \times 2.5 \mathrm{~cm}$ cells $)$ of 'Osaka White' were transplanted into 2.96-L (20.8$\mathrm{cm}$ diameter) round plastic containers on 29 Aug. 1999. The root substrate used was Fafard 4-P. Liquid fertilization at each irrigation was initiated on 5 Sept. with three $\mathrm{N}$ treatments of 150,200 , or $250 \mathrm{mg} \cdot \mathrm{L}^{-1}$ with $\mathrm{P}$ and $\mathrm{K}$ held constant at 8.8 and $166 \mathrm{mg} \cdot \mathrm{L}^{-1}$, respectively. Macronutrients and micronutrients were obtained from commercial-grade fertilizer salts to develop liquid concentrates applied at a 1: 100 ratio (Gibson, 2000). A supplemental application of $\mathrm{MgSO}_{4}$ at the rate of $243 \mathrm{mg} \cdot \mathrm{L}^{-1}$ $\mathrm{Mg}$ was applied monthly. Irrigation solution $\mathrm{pH}$ was adjusted to $\mathrm{pH} 5.5$ with sulfuric acid. Foliar sprays of daminozide at $2500 \mathrm{mg} \cdot \mathrm{L}^{-1}$ (using a volume of $204 \mathrm{~mL} \cdot \mathrm{m}^{-2}$ ) were applied on 13 and 30 Sept.Plants were grown outdoors under natural daylength. The experiment was a completely randomized design with five singleplant replicates sampled seven times.

On 29Aug., plant height and diameter were recorded for initial growth values. Beginning on 5 Sept., and continuing on a 2 -week interval until 28 Nov., plant height and diameter were recorded, and plant shoots were harvested to 
determine dry weight (g). Every 2 weeks, the "color diameter" (diameter of the whorl of colored leaves at the center of the plant at the widest dimension and also at $90^{\circ}$ from that dimension) was measured to determine if fertilization had an effect on color development.

Discontinuing fertilization (Expt. 3). Subgroups of 10 and five plants from each fertilizer rate in Expt. 2 were irrigated with tap water beginning on 31 Oct. [ 12 weeks after sowing (WAS)]. Two weeks later, data were collected to determine the effects of applying no additional fertilizer to ornamental cabbage. Five replications of the three tap water treatments were harvested for dry weight and tissue analysis on 14 Nov. (14 WAS) to be compared against continually fertilized plants. Also, on 14 and 28 Nov., plant height, plant diameter, and color diameter were measured. Elemental concentrations in tissue were determined as in Expt. 1.

Data were subjected to analysis of variance by general linear model and regressions determined by PROC REG (SAS Institute, Cary, N.C.). Means were separated by least significant differences (LSD) at $P \leq 0.05$.

\section{Results and Discussion}

\section{$\mathrm{N}$ and K Concentration (Expt. 1)}

Plant growth. Neither the $\mathrm{N} \times \mathrm{K}$ interaction, nor the $\mathrm{K}$ main effects were significant over time; therefore, only the effects on growth at the four levels of $\mathrm{N}$, which were significant, are presented. Plants increased in height over the 13-week period. Plants fertilized with $\mathrm{N}$ at 200 or $250 \mathrm{mg} \cdot \mathrm{L}^{-1}$ were $10 \%$ taller than those with $\mathrm{N}$ at $150 \mathrm{mg} \cdot \mathrm{L}^{-1}$, and $30 \%$ taller than those with $\mathrm{N}$ at $100 \mathrm{mg} \cdot \mathrm{L}^{-1}$ (Fig. 1A). No further increase in height was observed after week 10 for plants fertilized with $\mathrm{N}$ at only $100 \mathrm{mg} \cdot \mathrm{L}^{-1}$, and symptoms of $\mathrm{N}$ deficiency (purpling with a lighter green color of the lower foliage) appeared.

Plants reached their maximum diameter by week 10 (data not shown). Plants fertilized at $\mathrm{N}$ concentrations of 200 or $250 \mathrm{mg} \cdot \mathrm{L}^{-1}$ were significantly wider $(52.8$ and $53.6 \mathrm{~cm}$, respectively) than those fertilized with 100 or 150 $\mathrm{mg} \cdot \mathrm{L}^{-1}$, although a difference of $1.7 \mathrm{~cm}$ might have little commercial significance.

Coloration was first observed 12 WAS and was measured from 13 WAS until termination of the experiment. Data are not shown, as all plants had similar-sized color diameters $(5.3-6.7 \mathrm{~cm})$ regardless of $\mathrm{N}$ treatment. Fertilizer $\mathrm{N}$ rates of 200 and $250 \mathrm{mg} \cdot \mathrm{L}^{-1}$ did not delay color development or affect final color diameter, in contrast to reports by Luczai (1992), who stated that continual fertilization inhibits color development.

Before subjecting the plants to the 7.2 ${ }^{\circ} \mathrm{C}$ night temperature, uniform expansion of healthy green foliage was observed for the plants treated with $\mathrm{N}$ at 150 and $200 \mathrm{mg} \cdot \mathrm{L}^{-1}$. Plants grown with $\mathrm{N}$ at $250 \mathrm{mg} \cdot \mathrm{L}^{-1}$ resulted in foliage that was upright in leaf arrangement with the inner leaves having a cup-like habit, which made the plants look abnormally columnar. This characteristic may make the
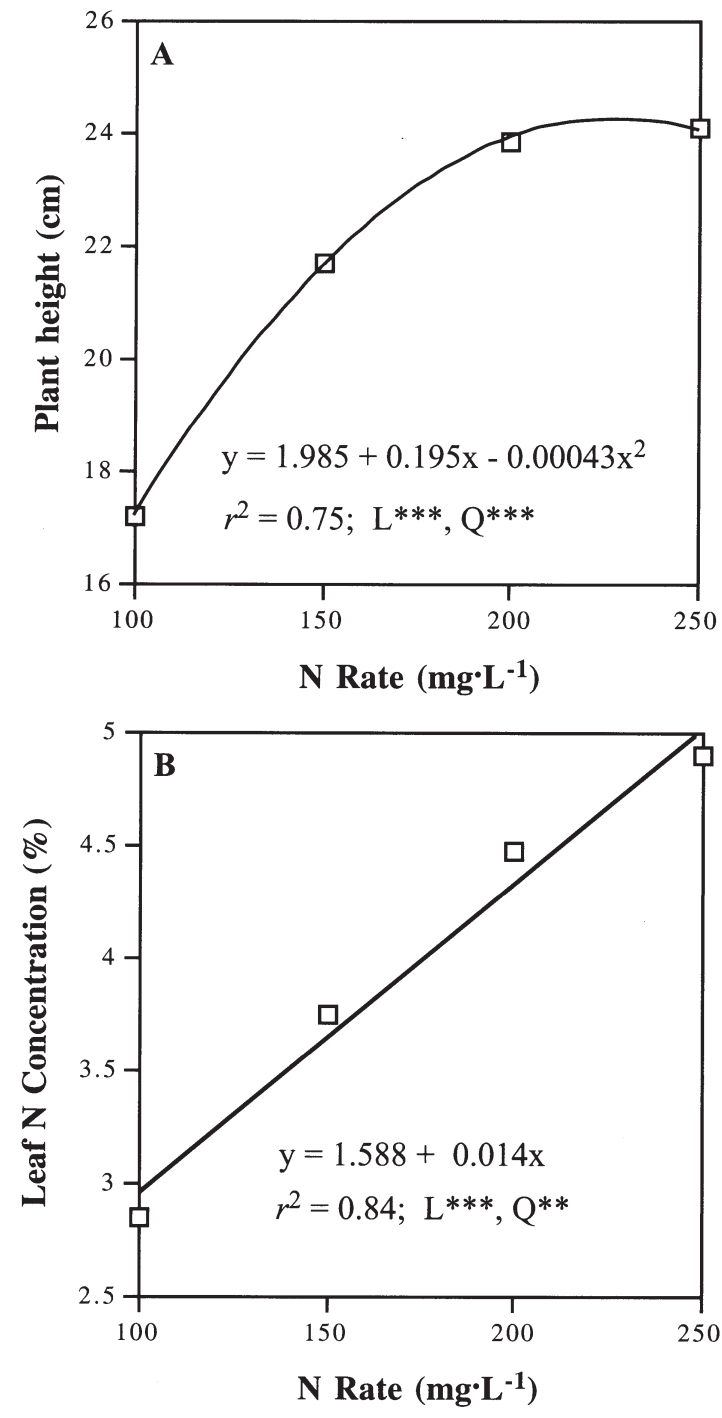

Fig. 1. Regression lines were generated from means of the treatments on $22 \mathrm{Apr}$. (13 WAS), and symbols are means of the treatments. ${ }^{* *},{ }^{* * *}$ Significant at $P \leq 0.01$ or 0.001 , respectively; $\mathrm{L}=$ linear; $\mathrm{Q}=$ quadratic. (A) The effect of nitrogen concentration on plant height of 'Osaka White' ornamental cabbage plants (Expt. 1) $(\mathrm{n}=20)$; (B) the effect of nitrogen concentration on leaf $\mathrm{N}$ concentration (Expt. 1) $(\mathrm{n}=20)$.

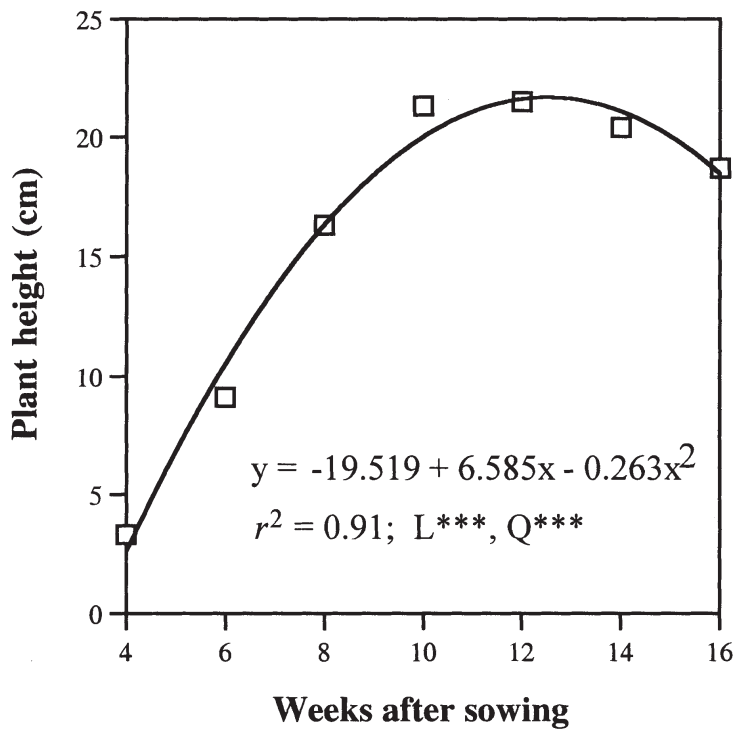

Fig. 2. Plant height of 'Osaka White' ornamental cabbage plants over time (Expt. 2). Regression lines were generated from means of the treatments, and symbols are means of the treatments $(\mathrm{n}=15) .{ }^{* * *}$ Significant at $P \leq 0.001 ; \mathrm{L}=$ linear; $\mathrm{Q}=$ quadratic. 
plants undesirable to the consumer.

Although $\mathrm{N}$ concentration did not have an effect on plant diameter, plant height was affected, and plants fertilized with $\mathrm{N}$ at 150 $\mathrm{mg} \cdot \mathrm{L}^{-1}$ were more suitable for wholesale production because more plants would fit on shipping carts. A nitrogen concentration of $200 \mathrm{mg} \cdot \mathrm{L}^{-1}$ produced taller plants than did lower $\mathrm{N}$ levels, a trait which may be desired by consumers.

Tissue analysis. Tissue $\mathrm{N}$ concentration increased with $\mathrm{N}$ fertilization rate (Fig. 1B). Plants treated with $\mathrm{N}$ at $100 \mathrm{mg} \cdot \mathrm{L}^{-1}$ had a tissue concentration of $2.86 \% \mathrm{~N}$, which was below the adequate range of $3.5 \%$ to $4.5 \%$ (Whipker et al., 1998). Based on regression analysis, the fertilization concentration should be $\geq 140 \mathrm{mg} \cdot \mathrm{L}^{-1} \mathrm{~N}$ to provide a foliar $\mathrm{N}$ concentration of $3.5 \%$.

As the concentration of $\mathrm{K}$ increased from 100 to $250 \mathrm{mg} \cdot \mathrm{L}^{-1}$, $\mathrm{K}$ tissue concentration also increased $(3.61 \%, 3.68 \%, 3.85 \%$, and $4.12 \%$, respectively, for $100,150,200$, and $250 \mathrm{mg} \cdot \mathrm{L}^{-1}$ K). Potassium fertilization rates of 100 to 200 $\mathrm{mg} \cdot \mathrm{L}^{-1}$ were within the acceptable range of $3.0 \%$ to $4.0 \%$ (Whipker et al., 1998), but $\mathrm{K}$ at $250 \mathrm{mg} \cdot \mathrm{L}^{-1}$ exceeded the range. This result suggests that fertilizing with $\mathrm{K}$ at $250 \mathrm{mg} \cdot \mathrm{L}^{-1}$ led to luxurious accumulation of K. For all N $\times \mathrm{K}$ fertilization concentrations, tissue concentrations of $\mathrm{Ca}$ and $\mathrm{Mg}$ were $0.8 \%$ to $0.9 \%$ and $0.5 \%$ to $0.6 \%$, respectively, and within the adequate range (Whipker et al., 1998).

\section{N Fertilization Concentration (Expt. 2)}

Plant growth. No significant differences occurred over time for the heights of plants fertilized with $\mathrm{N}$ at 150,200 , or $250 \mathrm{mg} \cdot \mathrm{L}^{-1}$. However, plants increased in height until week 14, then became shorter (Fig. 2). This reduction in plant height is due to the expansion of the colored foliage that arises from the center, causing the upper foliage to flatten and bend downward.

Diameters of plants fertilized with $\mathrm{N}$ at 150 $\mathrm{mg} \cdot \mathrm{L}^{-1}$ were significantly smaller throughout the growth period than those fertilized with $\mathrm{N}$ at either 200 or $250 \mathrm{mg} \cdot \mathrm{L}^{-1}$ (Fig. 3). The lower mature leaves bent downward as the plant developed center color and resulted in a reduction in plant diameter.

The trend of larger plant heights and diameters as $\mathrm{N}$ concentration increased with the outdoor study (Expt. 2) was similar to results from Expt. 1. Wholesale growers can fertilize with $\mathrm{N}$ at $150 \mathrm{mg} \cdot \mathrm{L}^{-1}$ to achieve smaller diameters for easier shipping, whereas retail growers could use $\mathrm{N}$ at $200 \mathrm{mg} \cdot \mathrm{L}^{-1}$ for large plants for retail customers.

The final dry weight of plants was significantly greater over time as the $\mathrm{N}$ fertilization rate increased from 150 to $250 \mathrm{mg} \cdot \mathrm{L}^{-1}$ (Fig. 4). At 14 weeks, the plants fertilized with $\mathrm{N}$ at $250 \mathrm{mg} \cdot \mathrm{L}^{-1}$ had $16 \%$ or $22 \%$ greater mass than plants fertilized with 200 or $150 \mathrm{mg} \cdot \mathrm{L}^{-1}$, respectively. At 16 weeks, differences were even more pronounced, as plants fertilized with $\mathrm{N}$ at $250 \mathrm{mg} \cdot \mathrm{L}^{-1}$ had $20 \%$ and $30 \%$ greater mass than those fertilized with $\mathrm{N}$ at 200 and $150 \mathrm{mg} \cdot \mathrm{L}^{-1}$, respectively.

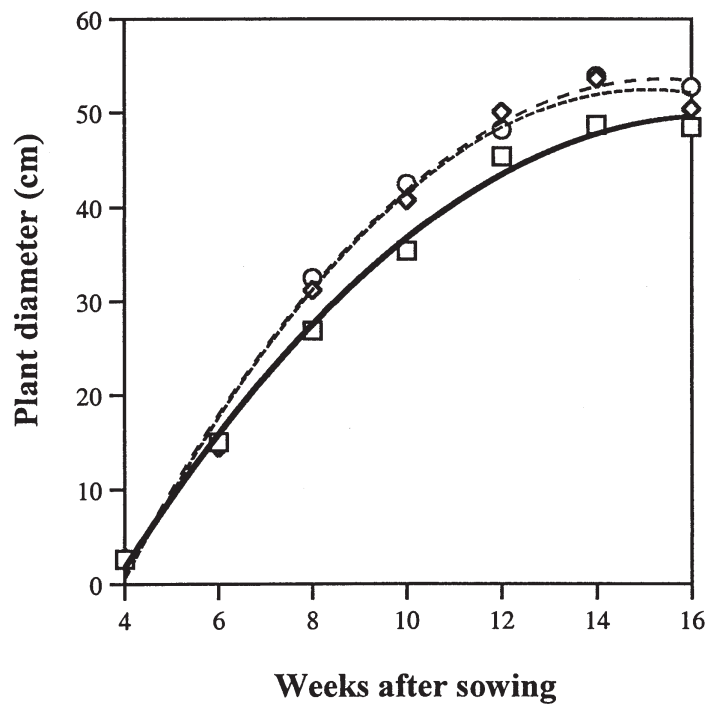

$$
\begin{array}{lll}
-\square-150 \mathrm{~N} & \mathrm{y}=-33.981+10.141 \mathrm{x}-0.307 \mathrm{x}^{2}, r^{2}=0.98 ; \mathrm{L}^{* * *}, \mathrm{Q}^{* * *} \\
--\diamond--- & 200 \mathrm{~N} & \mathrm{y}=-43.247+12.658 \mathrm{x}-0.419 \mathrm{x}^{2}, r^{2}=0.98 ; \mathrm{L}^{* * *}, \mathrm{Q}^{* * *} \\
--\mathrm{O}- & 250 \mathrm{~N} & \mathrm{y}=-42.052+12.411 \mathrm{x}-0.403 \mathrm{x}^{2}, r^{2}=0.99 ; \mathrm{L}^{* * *}, \mathrm{Q}^{* * *}
\end{array}
$$

Fig. 3. Plant diameter of 'Osaka White' ornamental cabbage plants over time (Expt. 2). Regression lines were generated from means of the treatments, and symbols are means of the treatments $(n=5) .{ }^{* * *}$ Significant at $P \leq 0.001 ; \mathrm{L}=$ linear; $\mathrm{Q}=$ quadratic.

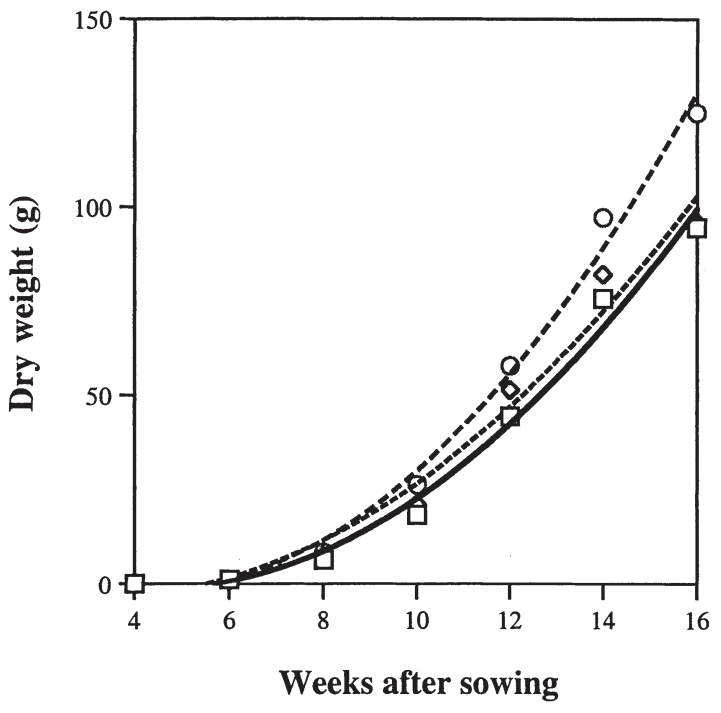

$$
\begin{array}{llll}
\longrightarrow \square-150 \mathrm{~N} & \mathrm{y}=12.341-6.373 \mathrm{x}+0.739 \mathrm{x}^{2}, r^{2}=0.98 ; \mathrm{L}^{* * *}, \mathrm{Q}^{* * *} \\
--\diamond--- & 200 \mathrm{~N} & \mathrm{y}=3.555-4.235 \mathrm{x}+0.653 \mathrm{x}^{2}, r^{2}=0.94 ; \mathrm{L}^{* * *}, \mathrm{Q}^{* * *} \\
-- \text { O- } & 250 \mathrm{~N} & \mathrm{y}=15.408-8.143 \mathrm{x}+0.958 \mathrm{x}^{2}, r^{2}=0.98 ; \mathrm{L}^{* * *}, \mathrm{Q}^{* * *}
\end{array}
$$

Fig. 4. Dry weight of 'Osaka White' ornamental cabbage plants over time (Expt. 2). Regression lines were generated from means of the treatments, and symbols are means of the treatments $(n=5)$. Ns, ${ }^{* * * *}$ Nonsignifcant or significant at $P \leq 0.001$, respectively; $\mathrm{L}=$ linear; $\mathrm{Q}=$ quadratic. 
Soll Management, Fertilization, \& Irrigation

Coloration. Nitrogen concentration had no effect on color diameter. Coloration was first observed 11 weeks after sowing, and color diameter was measured at $3.0 \mathrm{~cm}$ on week 12 (Fig. 5). Ornamental cabbage growers market plants based on the presence of visible center color and not color intensity (S. Hood, personal communication). At week 14, plants were of marketable size, plant diameter had reached its maximum size, and plants had a colored center of $\approx 17 \mathrm{~cm}$ in diameter. These results indicate that continuing to fertilize ornamental cabbage with $\mathrm{N}$ at 150 to $250 \mathrm{mg} \cdot \mathrm{L}^{-1}$ is not detrimental to center-head coloration. Therefore, growers can continue to fertilize through coloration and use cool temperatures below 12.7 to $15.5^{\circ} \mathrm{C}$ to influence color development.

Plant growth. After 2 weeks (14 WAS), no significant differences in plant height or diameter occurred for plants fertilized on a continual basis compared to plants receiving tap water. Differences occurred after 4 weeks of tap water irrigation, when the plants became significantly shorter in height and smaller in diameter than plants irrigated with tap water for 2 weeks or continually fertilized (data not shown). Differences in growth were due to lower leaf loss and stunting of plants receiving tap water irrigation.

Color diameters were similar for plants receiving tap water for 2,4 , or 6 weeks compared to plants on a continuous fertilizer program, and color diameter increased from $17.1 \mathrm{~cm}$ at week 14 to $23.2 \mathrm{~cm}$ by week 16 . This lack of effect of fertilizer duration on color diameter is in contrast to recommendations by Luczai (1998), who suggested that fertilization should be discontinued to induce coloration.

Tissue analysis. After only 2 weeks of discontinued fertilization, leaf concentrations of $\mathrm{N}, \mathrm{P}, \mathrm{K}$, and Ca were significantly reduced compared to concentrations in plants that were fertilized on a continual basis (Table 1). Tissue values of N, P, and K for the tap waterirrigated plants were below the adequate range (Whipker et al., 1998). The deficient nutrient levels occurred rapidly. The current grower recommendation of discontinuing fertilization would seem to promote the induction of nutrient deficiencies instead of the desired development of center color.

\section{Conclusions}

Nitrogen concentrations greater than 140 $\mathrm{mg} \cdot \mathrm{L}^{-1}$ were required for ornamental cabbage plants during both the establishment and coloration phases of growth in order to provide foliar $\mathrm{N}$ concentrations greater than the lower adequate range of $3.5 \%$. Fertilizing with 8 to $10 \mathrm{mg} \cdot \mathrm{L}^{-1} \mathrm{P}, 150$ to $200 \mathrm{mg} \cdot \mathrm{L}^{-1} \mathrm{~K}, 100 \mathrm{mg} \cdot \mathrm{L}^{-1}$ $\mathrm{Ca}$, and $50 \mathrm{mg} \cdot \mathrm{L}^{-1} \mathrm{Mg}$ on a continual basis was required to provide adequate plant growth. In Expt. 2, no differences in plant height occurred

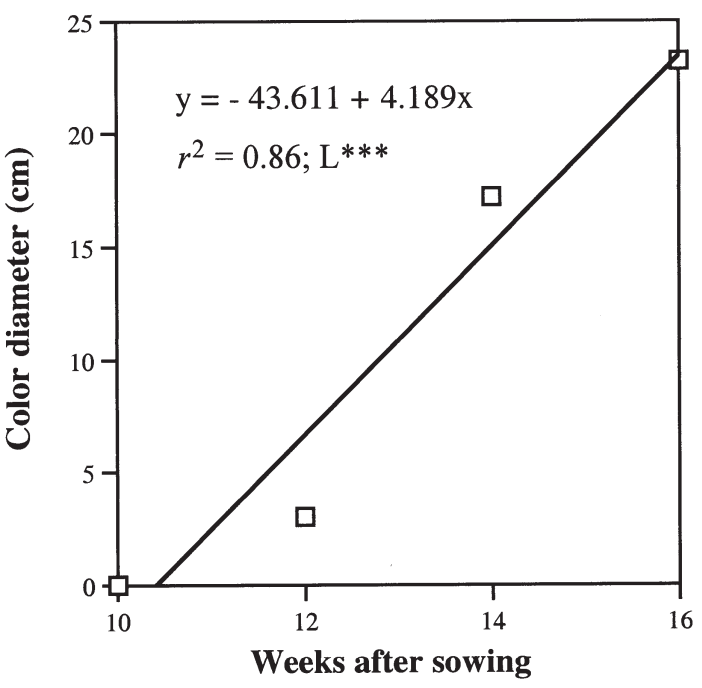

Fig. 5. The development of color diameter over time of 'Osaka White' ornamental cabbage plants (Expt. 2). Regression lines were generated from means of the treatments, and symbols are means of the treatments $(\mathrm{n}=15)$. ${ }^{* * *}$ Significant at $P \leq 0.001 ; \mathrm{L}=$ linear; $\mathrm{Q}=$ quadratic.

Table 1. The elemental concentration for ornamental cabbage tissue of plants continually fertilized or subjected to tap water for 2 weeks (Expt. 2).

\begin{tabular}{lcccc}
\hline Treatment & Leaf N concn $(\%)$ & Leaf P concn $(\%)$ & Leaf K concn $(\%)$ & Leaf Ca concn $(\%)$ \\
\hline CLF $^{2}$ & 5.08 & 0.32 & 3.42 & 0.91 \\
Tap water & $3.19^{* * *}$ & $0.19^{* * *}$ & $2.39^{* * *}$ & $0.77^{* * *}$ \\
\hline
\end{tabular}

${ }^{7}$ Continual liquid fertilization.

****** Significant at $P \leq 0.01$ or 0.001 , respectively.

with $\mathrm{N}$ at 150 to $250 \mathrm{mg} \cdot \mathrm{L}^{-1}$, but plant diameters increased with higher $\mathrm{N}$ concentrations. Therefore, growers should select a fertilization concentration that matches the marketing system, ranging from $150 \mathrm{mg} \cdot \mathrm{L}^{-1} \mathrm{~N}$ for wholesale growers who require a greater density of plants on shipping carts to $200 \mathrm{mg} \cdot \mathrm{L}^{-1} \mathrm{~N}$ for retail growers who may desire large-sized plants.

Center-head coloration was not inhibited by $\mathrm{N}$ concentrations as high as $250 \mathrm{mg} \cdot \mathrm{L}^{-1}$. Discontinuing fertilization prior to coloration resulted in the rapid depletion of $\mathrm{N}, \mathrm{P}, \mathrm{K}$, and $\mathrm{Ca}$ tissue concentrations in the lower foliage, leading to the appearance of deficiency symptoms and lower leaf loss. Traditional fertilization practices for many floriculture crops at visible flower bud development suggest that fertilization be discontinued or reduced significantly because plants require less nutrients for growth during anthesis (Nell, 1993). Anthesis of ornamental cabbage occurs only after a vernalization period (Opena et al., 1993), which may be months after visible center-head color. During the time when anthocyanin production occurs, dry weight was still increasing, and nutrient demands were still high. Therefore, ornamental cabbage should still be considered an exception to other floriculture crops, as fertilization needs to be continued through center-head coloration in order to maintain adequate nutrient levels.

\section{Literature Cited}

Galinat, W.C. 1995. Temperature sensitivity in ornamental corn and kale. Maize Genet. Coop. Nwsl. 69:132.

Gibson, J.L. 2000. The chemical growth regulation and fertility management of ornamental cabbage and kale. MS Thesis, Dept. of Horticulture, North Carolina State Univ., Raleigh.

Luczai, R.T. 1992. Flowering cabbage and kale: Ideal for use in late fall landscapes. Professional Plant Growers Assn. News 23(4):2-3.

Marquardt, B. and R. Schlemmer. 1996. Flowering kale: Fall color for late sales. GrowerTalks 60(3):68-69.

McAvoy, R.J. 1994. Cultural tips for ornamental cabbage and kale. Conn. Greenhouse Nwsl., No. 180, June/July, p. 13-15.

Nell, T.A. 1993. Flowering pot plants: Prolonging shelf performance. Ball Publ., Batavia, Ill.

Opena, R.T., C.G. Kuo, and J.Y. Yoon. 1988. Breeding and seed production of chinese cabbage in the tropics and subtropics. Tech. Bul. No. 17. Asian Veg. Res. and Dev. Ctr., Shanhua, Taiwan.

Salisbury, F.B. and C.W. Ross. 1992. Plant physiology, 4th ed. Wadsworth Publ., Belmont, Calif.

Taiz, L. and E. Zeiger. 1998. Plant physiology, 2nd ed. Sinauer Assoc., Sunderland, Mass.

Whipker, B.E., J.L. Gibson, R.A. Cloyd, C.R. Campbell, and R. Jones. 1998. Success with ornamental cabbage and kale. N.C. State Univ. Hort. Info. Lfit. 507. 19 Apr. 2000. <www.ces.ncsu.edu/ depts/hort/floriculture/hils/HIL507.pdf>. 